\title{
Macroeconomic determinants of Port and Douro wine exports: An econometric approach
}

\author{
Anthony Macedo, Sofia Gouveia, João Rebelo ${ }^{1}$ \\ ${ }^{1}$ University of Trás-os-Montes and Alto Douro, Vila Real, Portugal
}

Received: 2 April 2020/Accepted: 2 November 2020

\begin{abstract}
This study analyses recent trends (2006-2018) in Port and Douro wine exports and estimates their macroeconomic determinants. The results of the gravity equation reveal that the gross domestic product in importing countries is the most important export determinant of both wines, and Douro wine exports are negatively affected by the distance to the destination country, but positively influenced by sharing a common language and the level of wine production in importing countries. Therefore, in order to increase exports, the industry's strategic decision-makers should pay special attention to the markets in wealthier countries or with a high potential for economic growth, taking into account issues such as market access, adaptation of the market to wine consumption, and regulation.
\end{abstract}

Key words: International trade, Gravity model, Poisson pseudo-maximum likelihood, Wine, Demarcated Douro region

\section{Introduction}

During the last 50 years, the international wine market has dramatically changed. New competitors appeared on the international scene and joined the top wine producers and exporters. Initially, the production and exports were concentrated in a small number of European countries, the Old World, namely France, Italy, Spain, Portugal and Germany. Since the 1950s, a new set of wine producing and exporting countries emerged, the New World (South Africa, Argentina, Australia, United States of America, and New Zealand). In recent years there appeared a second new group of wine producers, the New New World, including China, India, Brazil, and the countries around the Black Sea (Cardebat 2019). It is expected that the relatively new hierarchy of wine-producing countries could remain in place for the ten next years, but a process of convergence between Old and New World seems to be under way (Holmes, Anderson 2017, Morrison, Rabellotti 2017, Bargain et al. 2018), with consequences for wine output and also in the market of inputs, including direct investment and labour market.

Portugal is a historical wine-producing country, with a rich history, where wine is inseparable from the culture, heritage, terroirs and economy of the country. Representative of this history is the wine from the Demarcated Douro Region (DDR), demarcated since 1756. This region fits the typical terroir model and it is the largest and the most heterogeneous wine mountain region in the world, with high production costs and low productivity. Essentially the two main types of wines produced in this region are Port 


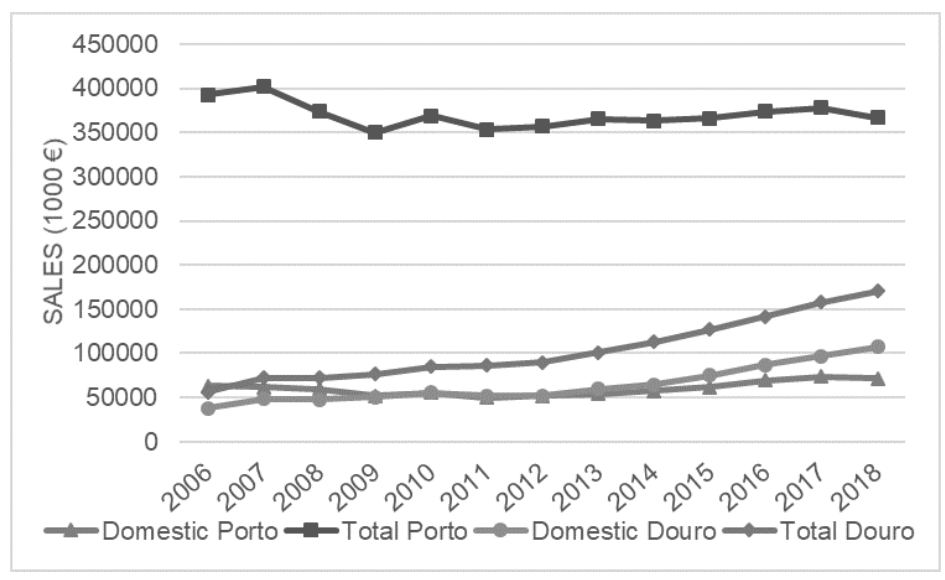

Source: Authors' computation from IVDP data.

Figure 1: The evolution of total Port and Douro wine sales and domestic market, 2006-2018

Table 1: Main destination countries of Port wine exports, in real value (million $€$ ), 2006 and 2018

\begin{tabular}{ccccccc}
\hline $\mathrm{R}$ & Country & 2006 & $\%$ & Country & 2018 & $\%$ \\
\hline 1 & France & 92 & 28 & France & 75 & 25 \\
2 & United Kingdom & 52 & 16 & United Kingdom & 44 & 15 \\
3 & Netherlands & 49 & 15 & Netherlands & 38 & 13 \\
4 & Belgium & 42 & 13 & USA & 36 & 12 \\
5 & USA & 35 & 11 & Belgium & 31 & 11 \\
6 & Canada & 17 & 5 & Denmark & 15 & 5 \\
7 & Germany & 10 & 3 & Germany & 12 & 4 \\
8 & Denmark & 7 & 2 & Canada & 11 & 4 \\
9 & Spain & 6 & 2 & Spain & 4 & 1 \\
10 & Switzerland & 4 & 1 & Switzerland & 4 & 1 \\
& Top 10 & 313 & 95 & Top 10 & 240 & 91 \\
& World & 330 & 100 & World & 295 & 100 \\
\hline
\end{tabular}

Source: Authors' computation from IVDP data.

Notes: $\mathrm{R}=$ ranking; $\%=$ share of total Port wine exports; real values computed using export deflator of goods from Banco de Portugal; USA = United States of America.

(fortified) and Douro (still) wines, each one presenting a completely different history and market position. With a total sale of 6,389 million euro in the period 2006-2018, Port wine represented $75 \%$ and Douro wine $21 \%$, these two wines are the core of the region.

Port wine has a successful presence in the international markets for more than three centuries, currently exporting almost $80 \%$ of its total sales, although suffering declining sales in the last decade. Unlike the Port wine, the commercial history of Douro is much shorter - just thirty years, it is a new entrant in the mature international market, and its exports represent almost $40 \%$ of the total sales. Both wines are sold (on average) at a lower price than the average price of wine in the EU (Hogg, Rebelo 2018).

As shown in Figure 1, the recent trend of Port wine sales reveals a slight decrease of $7 \%$ in total sales from 2006 to 2018 .

The share of domestic sales for Port wine increased from 16\% to $20 \%$ between 2006 and 2018, becoming in the last year the most important market for the first time in many years, replacing France as the main market. This was probably encouraged by the boom in tourism which has occurred in Portugal, especially in the Porto-Gaia region. The growth in domestic sales is also explained intrinsically by a worse performance in foreign markets (Table 1). Comparing 2018 to 2006, exports decreased from 330 to 295 million euro (in real terms). 
Table 2: Main destination countries of Douro wine exports, in real value (million $€$ ), 2006 and 2018

\begin{tabular}{ccccccc}
\hline $\mathrm{R}$ & Country & 2006 & $\%$ & Country & 2018 & $\%$ \\
\hline 1 & Canada & 3,1 & 17 & Canada & 12,1 & 19 \\
2 & USA & 2,1 & 12 & United Kingdom & 8,2 & 13 \\
3 & Brazil & 1,9 & 11 & Brazil & 6,5 & 10 \\
4 & France & 1,5 & 8 & Switzerland & 5,8 & 9 \\
5 & Germany & 1,5 & 8 & Germany & 4,8 & 8 \\
6 & Switzerland & 1,4 & 8 & USA & 4,5 & 7 \\
7 & Norway & 1,1 & 6 & Angola & 2,9 & 5 \\
8 & United Kingdom & 1,1 & 6 & France & 2,5 & 4 \\
9 & Angola & 0,8 & 4 & Belgium & 2,5 & 4 \\
10 & Belgium & 0,7 & 4 & China & 2,3 & 4 \\
& Top 10 & 15 & 84 & Top 10 & 52 & 82 \\
& World & 18 & 100 & World & 64 & 100 \\
\hline
\end{tabular}

Source: Authors' computation from IVDP data.

Notes: $\mathrm{R}=$ ranking; $\%=$ share of total Douro wine exports; real values computed using export deflator of goods from Banco de Portugal; USA = United States of America.

Compared with Port wine, Douro wine sales presented a different trend (Figure 1). Between 2006 and 2018, total sales increased 205\% and domestic sales 183\%. As it can be observed in Table 2, during the period of study, exports of Douro wine increased from 18 million euro (in real terms) to 64 million euro.

The comparison of Tables 1 and 2 highlights the high concentration of Port wine exports to European countries (USA and Canada are the only non-European countries in the top 10), while Douro wine exports are more dispersed, with the particularity of Portuguese-speaking countries being important destinations.

Since the cost of grape production are high in the DDR, due to high labour costs and low yields, and adding the increased competition in the international wine market, the DDR wine industry faces a double challenge. On the one hand, to break the negative trend of Port wine sales and, on the other hand, to achieve a higher valuation of both wines (Hogg, Rebelo 2018). In this way, a better knowledge of the macroeconomic determinants of international demand for Port and Douro wine may contribute to the achievement of these goals.

Thus, based on data provide by IVDP, a panel econometric model is applied to a gravity equation, considering the period 2006-2018 and 80 main destination countries of both wines. This work also contributes to the enrichment of the wine economics literature on international trade by comparing the exports determinants of two wines produced in the same region, through the use of two estimation approaches.

After this introduction, the next section is dedicated to the theoretical framework. In Section 3 data and results are presented. Finally, section 4 concludes the study.

\section{Theoretical framework: The gravity equation}

As countries or sectors have turned toward export-led growth strategies, the estimation of export equations has become more relevant to support policy decisions. Bayar (2018) grouped export equations into four levels of analysis, from macro to micro: aggregated level exports, country-level, sector-level and firm-level analysis or combinations of them, each one requiring the availability of specific data. The research included in this work is a mix between country-level and sector-level analysis. On the one hand, as in most country-level analysis, the gravity equation is formulated with explanatory variables representing trade frictions or trade facilitators between countries. On the other hand, it is focused on a single product, examining sector-specific characteristics, as in sector-level analysis. 
Gravity equations started to be developed in the 1960's, however it took some time for the link between the model and trade theory to be demonstrated by several authors (Anderson 1979, Anderson, van Wincoop 2003, Bergstrand 1989, Eaton, Kortum 2002, Helpman 1987, Helpman, Krugman 1985). Starting from a model explaining that trade flows are negatively affected by bilateral distance between two trade partners whilst being positively affected by the respective economic masses, researchers then developed the gravity model to address more trade frictions/facilitators.

The literature analysing world wine trade with the gravity model (Castillo et al. 2016, Dal Bianco et al. 2016, Dascal et al. 2002, Gouveia et al. 2018, Macedo et al. 2019, 2020) is the base for the following export function of Port and Douro wines:

$$
\text { exports }_{w, i t}=f\left(g d p_{i t}, e r_{i t}, e u_{i t}, \text { ave }_{w, i t}, \operatorname{prod}_{i t}, \text { dist }_{i}, \text { land }_{i}, \operatorname{lang}_{i}\right)
$$

Where the dependent variable exports represents the exports of wine $w$ (Port or Douro) to country $i$ in year $t$. Among the explanatory variables there are typical variables of gravity equations, such as the GDP of country $i$ in year $t(g d p)$, the average annual exchange rate of country $i$ 's currency in relation to the euro in year $t(e r)$, a dummy variable equal to 1 if country $i$ is member of the European Union (EU) in year $t$ or 0 otherwise $(e u)$, the geographical distance between Lisbon and the capital city of country $i$ (dist), a dummy variable equal to 1 if country $i$ is landlocked (land), and a dummy variable equal to 1 if country $i$ has a common official language with Portugal (lang). Because the research is focused in each wine, considered equivalent to a single sector, two explanatory variables were specifically included to represent sectoral characteristics (Bayar 2018), which are the ad valorem equivalent tariff applied by country $i$ to wine $w$ (Port or Douro) imports in year $t$ (ave) and the litres of wine produced by the importing country in year $t($ prod $)$.

In order to overcome problems of specification of the gravity equation, multilateral resistance terms should be considered (Anderson, van Wincoop 2003) and, following Head, Mayer (2014), two different approaches are used to deal with this issue. The first one is derived from "remoteness indexes" (Baldwin, Harrigan 2011, Wei 1996) and calculated through weighting bilateral distance with the degree of trade openness of the importing country (distw), so it is expected that the costs associated to transport decreases as openness increases, due to economies of scale in transport.

The alternative solution to proxy multilateral resistance terms is to consider countries fixed effects (Dal Bianco et al. 2016, Dal Bianco et al. 2017, Macedo et al. 2020, Santeramo et al. 2019), not requiring strong structural assumptions on the underlying model (Head, Mayer 2014). However, its main drawback is not allowing estimation of the coefficients for time-invariant variables (such as distance, landlockedness, and common language).

Another well-known issue in gravity equations is the "zero problem". For a long time, gravity equations were estimated with linear methods using the logarithm of exports as a dependent variable, resulting in an undefined logarithm of zero when there was no trade between two countries. To overcome this drawback, several approaches were put forward, the seminal one being proposed by Silva, Tenreyro (2006). They avoid the log-form using a multiplicative form and, additionally, recommend a non-linear estimation method, preferably Poisson pseudo-maximum likelihood (PPML).

Using the PPML method, the following gravity equations for Port and Douro wine exports are estimated:

$$
\begin{aligned}
\text { exports }_{w, i t}= & \exp \left[\beta_{1} \ln g d p_{i t}+\beta_{2} \ln \text { er }_{i t}+\beta_{3} \ln \left(\text { ave }_{w, i t}+1\right)+\beta_{4} \text { eu }_{i t}+\right. \\
& \left.\beta_{5} \ln \operatorname{prod}_{i t}+\beta_{6} \text { land }_{i}+\beta_{7} \text { lang }_{i}+\beta_{8} \ln \text { dist }_{i t}+\varphi_{t}+u_{i t}\right] \\
\text { exports }_{w, i t}= & \exp \left[\beta_{1} \ln g d p_{i t}+\beta_{2} \ln \text { er }_{i t}+\beta_{3} \ln \left(\text { ave }_{w, i t}+1\right)+\beta_{4} \text { eu }_{i t}+\right. \\
& \left.\beta_{5} \ln \operatorname{prod}_{i t}+\omega_{i}+\varphi_{t}+u_{i t}\right]
\end{aligned}
$$

Equation (2) stands for the method considering time-invariant variables and equation (3) includes importing countries fixed effects $\left(\omega_{i}\right)$. Time fixed effects $\left(\varphi_{t}\right)$ are included, and the statistical error $\left(u_{i t}\right)$ is assumed to be identically and independently distributed. Explanatory variables are in the log-form, dummy variables being the exception. 
Table 3: Data sources and descriptive statistics

\begin{tabular}{|c|c|c|c|c|c|c|c|c|}
\hline Variables & Data Source & Unit & $\mathrm{N}$ & Mean & P50 & $\mathrm{SD}$ & Min & Max \\
\hline exports $_{\text {Port }}$ & IVDP & $10^{3} €$ & 1032 & 3891 & 118 & 12218 & 0 & 87688 \\
\hline exports & IVDP & $10^{3} €$ & 1040 & 492 & 20 & 1247 & 0 & 11238 \\
\hline gdp & WDI & $10^{9} €$ & 1036 & 647 & 150 & 1779 & 0.1 & 17405 \\
\hline er & WDI & LCU per $€$ & 1040 & 565 & 6 & 3136 & 0.3 & 39857 \\
\hline ave $_{\text {Port }}$ & Macmap & $\%$ & 974 & 12.9 & 1.4 & 23.3 & 0 & 150 \\
\hline ave $_{\text {Douro }}$ & Macmap & $\%$ & 974 & 12.8 & 1.0 & 23.2 & 0 & 150 \\
\hline $\mathrm{eu}$ & EU & Binary & 1040 & 0.3 & 0.0 & & 0 & 1 \\
\hline prod & OIV & $10^{3} \mathrm{hl}$ & 1040 & 3222 & 65 & 8935 & 0 & 54800 \\
\hline distw & WDI/CEPII & Weighted km & 1036 & 15092 & 9394 & 15507 & 969 & 78030 \\
\hline lang & CEPII & Binary & 1040 & 0.1 & 0 & & 0 & 1 \\
\hline land & CEPII & Binary & 1040 & 0.1 & 0 & & 0 & 1 \\
\hline
\end{tabular}

Source: Authors' computation.

Notes: IVDP = Instituto de Vinhos do Douro e do Porto (https://www.ivdp.pt/); WDI = World Development Indicators (https://databank.worldbank.org/source/world-development-indicators); Macmap = Market Access Map (https://www.macmap.org/en/query/customs-duties); OIV = International Organisation of Vine and Wine (http://www.oiv.int/en/statistiques/recherche); CEPII = (http://www.cepii.fr/cepii/en/bdd_modele/presentation.asp?id=6); hl = hectolitres; LCU = local currency unit; $\mathrm{km}=$ Kilometres $\mathrm{N}=$ number of observations; P50 = median; $\mathrm{SD}=$ standard deviation; Min $=$ minimum value; Max $=$ maximum value; For the binary variables the mean represents the percentage of observations equal to one.

\section{Data and results}

Table 3 introduces the data sources and the main descriptive statistics. The data for Port and Douro wine exports were extracted from the website of IVDP and they cover a sample of 80 importing countries from 2006 to 2018 (99\% of total exports during the period of study).

Table 4 presents the results of the estimations of equation (2) in columns (I) and (III), and the results of the estimations of equation (3) in columns (II) and (IV). Time effects are statistically significant, which are considered using yearly dummy variables (omitted due to space considerations). Standard errors account for intra-group correlation. The Wald test was applied to compare the estimated coefficients for Port and Douro wines and the results $\left(\chi_{21}^{2}=7412.70\right.$ comparing columns I and III and $\chi_{17}^{2}=7768.04$ comparing columns II and IV) suggest they are statistically different. Therefore, export determinants of Douro and Port wines are fairly different.

Starting from the analysis of gravity variables, GDP presents in the four models a positive and statistically significant coefficient and the magnitude of the coefficients is considerably higher in columns (I) and (III), which highlights the importance of including countries fixed effects to not overstate the effect of GDP. The positive effect of GDP is in line with the results of previous research, suggesting that wine exports increases with the size of the destination market. ${ }^{1}$

The distance, present in columns (I) and (III), is only statistically significant for Douro wine and has the expected negative effect. Ceteris paribus, this means that, on average, relatively more distant importing countries import less Douro wine due to higher transport costs. For Port wine, the estimated coefficient is not significant, converging with the results of Gouveia et al. (2018), which can be explained by the observation that the main importers of Port wine are European Union countries. Therefore, distance plays a lesser role for Port wine exports than for Douro wine, whose exports are more spread around the world.

Regarding the other time-invariant variables, the importing country being landlocked is not a statistically significant determinant for the exports of any of the wines. Sharing a common official language has a significant impact only for Douro wine, which can be supported by the good commercial relationship with former colonies, such as Angola

\footnotetext{
${ }^{1}$ This result is different from the one presented by Gouveia et al. (2018), in which GDP has not a statistically significant effect on Port wine exports, but this may be due to potential high correlation with another significant and positive regressor considered by the authors, the per capita GDP.
} 
Table 4: Estimation of a gravity model for Port and Douro wine exports (in €), 2006-2018

\begin{tabular}{|c|c|c|c|c|}
\hline Variables & $\begin{array}{c}(\mathrm{I}) \\
\text { Port } \\
\text { PPML }\end{array}$ & $\begin{array}{c}\text { (II) } \\
\text { Port } \\
\text { PPML-FE }\end{array}$ & $\begin{array}{c}\text { (III) } \\
\text { Douro } \\
\text { PPML }\end{array}$ & $\begin{array}{c}\text { (IV) } \\
\text { Douro } \\
\text { PPML-FE }\end{array}$ \\
\hline $\ln g d p_{i t}$ & $\begin{array}{c}0.903^{* * *} \\
(0.235)\end{array}$ & $\begin{array}{c}0.825^{* * *} \\
(0.183)\end{array}$ & $\begin{array}{c}1.022^{* * *} \\
(0.351)\end{array}$ & $\begin{array}{c}0.545^{* *} \\
(0.271)\end{array}$ \\
\hline $\ln e r_{i t}$ & $\begin{array}{c}0.055 \\
(0.196)\end{array}$ & $\begin{array}{c}0.042 \\
(0.194)\end{array}$ & $\begin{array}{c}0.026 \\
(0.162)\end{array}$ & $\begin{array}{l}-0.264 \\
(0.241)\end{array}$ \\
\hline $\ln \left(a v e_{w, i t}+1\right)$ & $\begin{array}{c}0.051 \\
(0.102)\end{array}$ & $\begin{array}{c}0.051 \\
(0.105)\end{array}$ & $\begin{array}{l}-0.099 \\
(0.113)\end{array}$ & $\begin{array}{l}-0.095 \\
(0.111)\end{array}$ \\
\hline$e u_{i t}$ & $\begin{array}{c}0.519 \\
(0.386)\end{array}$ & $\begin{array}{c}0.533 \\
(0.390)\end{array}$ & $\begin{array}{c}0.044 \\
(0.428)\end{array}$ & $\begin{array}{c}0.100 \\
(0.442)\end{array}$ \\
\hline $\ln \operatorname{prod}_{i t}$ & $\begin{array}{l}-0.019 \\
(0.056)\end{array}$ & $\begin{array}{l}-0.023 \\
(0.056)\end{array}$ & $\begin{array}{l}0.183^{*} \\
(0.094)\end{array}$ & $\begin{array}{c}0.130 \\
(0.102)\end{array}$ \\
\hline $\ln d i s t w_{i t}$ & $\begin{array}{l}-0.173 \\
(0.246)\end{array}$ & & $\begin{array}{c}-0.771^{* * *} \\
(0.192)\end{array}$ & \\
\hline $\operatorname{land}_{i}$ & $\begin{array}{l}-0.085 \\
(0.555)\end{array}$ & & $\begin{array}{c}-0.044 \\
(1.231)\end{array}$ & \\
\hline $\operatorname{lang}_{i}$ & $\begin{array}{c}0.370 \\
(1.214)\end{array}$ & & $\begin{array}{c}5.549^{* * *} \\
(1.251)\end{array}$ & \\
\hline Constant & $\begin{array}{l}-8.004 \\
(5.208)\end{array}$ & & $\begin{array}{l}-8.554 \\
(7.976)\end{array}$ & \\
\hline Observations & 963 & 963 & 970 & 970 \\
\hline $\begin{array}{l}\text { Time effects' } \\
\text { significance }\end{array}$ & $\begin{array}{c}151.15^{* * *} \\
{[0.000]}\end{array}$ & $\begin{array}{c}133.30 * * * \\
{[0.000]}\end{array}$ & $\begin{array}{c}410.50^{* * *} \\
{[0.000]}\end{array}$ & $\begin{array}{c}373.60 * * * \\
{[0.000]}\end{array}$ \\
\hline
\end{tabular}

Source: Authors' computation.

Notes: Robust standard errors in ( ); ${ }^{* * *} \mathrm{p}<0.01,{ }^{* *} \mathrm{p}<0.05,{ }^{*} \mathrm{p}<0.1$; p values in [ ].

and Brazil, that allows Portuguese still wines to capture important market share. This result was also pointed to by Macedo et al. (2019). However, for historical reasons, these countries have never been important destination markets of Port wine, thus the estimated coefficient is not significant.

Concerning the results associated with wine production in the importing country, the estimated coefficients are almost all nonsignificant, with the exception of the barely statistically significant coefficient in column (III). For Port wine, following Macedo et al. (2020), this effect may be explained by the phenomenon that the top wine-producing countries do not find a valid substitute for Port wine in their domestic markets. This is also a possible explanation for Douro wine, but it is more likely that Douro wine arouses greater interest in more mature wine markets. As Macedo et al. (2019) suggest, taste for Douro wine is not homogeneous across the world, with some countries valuing quality more than others when they choose among distinct categories of Douro wines.

Regarding ad valorem equivalent tariffs, they do not have a statistically significant effect. This result was also highlighted by Gouveia et al. (2018) and Macedo et al. (2020), suggesting that the differentiating characteristics of these two wines more than compensate for customs duties. However, another explanation may lie in the fact that changes in tariffs have been scarce in recent years and fixed effects capture their impact. Additionally, neither the exchange rate nor the dummy variable for EU membership present statistically significant coefficients.

\section{Conclusion}

The results point to some discrepancy in export determinants between Douro and Port wines. The GDP of importing countries is a crucial determinant for both wines, with an increase in GDP provoking a positive variation of exports. Additionally, some inference can be made to point to specific determinants. For example, Douro wine is negatively 
influenced by the distance of the importing country and its marketability may increase in more mature wine markets or countries speaking Portuguese. Besides, exports of Port and Douro wine are not significantly influenced by the wine production in the importing country, exchange rates, tariffs, the importer being member of the EU, or the importer not having direct access to the sea.

From the results it can be concluded that decision-makers from the DDR wine industry can increase exports aimed at markets with high GDP or potential for economic growth. However, increasing international competitiveness can only be achieved via supporting market access, wine quality adaptation to the market, and appropriate regulation. As stated by Hogg, Rebelo (2018), to increase exports it is necessary to gain better knowledge of both markets and consumers, which can then be used to attract new consumers, and promote online sales through digital marketing tools. Further, it is necessary to create better and more effective regulation that will be able to address the market challenges.

\section{References}

Anderson JE (1979) A theoretical foundation for the gravity equation. The American Economic Review 69: 106-116. CrossRef.

Anderson JE, van Wincoop E (2003) Gravity with gravitas: A solution to the border puzzle. The American Economic Review 93: 170-192. CrossRef.

Baldwin R, Harrigan J (2011) Zeros, quality, and space: trade theory and trade evidence. American Economic Journal: Microeconomics 3: 60-88. CrossRef.

Bargain O, Cardebat JM, Chiappini R, Laffitte C (2018) Long-term prospects of the international wine trade. Journal of Wine Economics 13: 461-468. CrossRef.

Bayar G (2018) Estimating export equations: A survey of the literature. Empirical Economics 54: 629-672. CrossRef.

Bergstrand JH (1989) The generalized gravity equation, monopolistic competition, and factor proportions theory in international trade. The Review of Economics and Statistics 71: 143-153. CrossRef.

Cardebat JM (2019) Introduction: Does a national model exist which favors trade performance? In: Ugaglia A, Cardebat JM, Corsi A (eds), The Palgrave Handbook of Wine Industry Economics. Palgrave Macmillan, 455-461

Castillo JS, Villanueva EC, García-Cortijo MC (2016) The international wine trade and its new export dynamics (1988-2012): A gravity model approach. Agribusiness 32: 466-481. CrossRef.

Dal Bianco A, Boatto VL, Caracciolo F, Santeramo FG (2016) Tariffs and non-tariff frictions in the world wine trade. European Review of Agricultural Economics 43: 31-57. CrossRef.

Dal Bianco A, Estrella-Orrego MJ, Boatto VL, Gennari AJ (2017) Is Mercosur promoting trade? Insights from Argentinean wine exports. Spanish Journal of Agricultural Research 15: 1-10. CrossRef.

Dascal D, Mattas K, Tzouvelekas V (2002) An analysis of EU wine trade: A gravity model approach. International Advances in Economic Research 8: 135-147. CrossRef.

Eaton J, Kortum S (2002) Technology, geography, and trade. Econometrica 70: 1741-1779. CrossRef.

Gouveia S, Rebelo J, Lourenço-Gomes L (2018) Port wine exports: A gravity model approach. International Journal of Wine Business Research 30: 218-242. CrossRef.

Head K, Mayer T (2014) Gravity equations: Workhorse, toolkit, and cookbook. In: Gopinath G, Helpman E, Rogoff K (eds), Handbook of International Economics, Volume 4. Elsevier, 131-195 
Helpman E (1987) Imperfect competition and international trade: Evidence from fourteen industrial countries. Journal of the Japanese and International Economies 1: 62-81. CrossRef.

Helpman E, Krugman P (1985) Market structure and foreign trade: Increasing returns, imperfect competition and the international economy. MIT Press, Cambridge

Hogg T, Rebelo J (2018) Rumo estratégico para o setor dos vinhos do Porto e Douro. IVDP/UTAD report, Porto. http://www.ivdp.pt/pt/docs/SINTESE.pdf

Holmes JA, Anderson K (2017) Convergence in national alcohol consumption patterns: New global indicators. Journal of Wine Economics 12: 117-148. CrossRef.

Macedo A, Gouveia S, Rebelo J (2019) Does wine quality have a bearing on exports? Agris on-line Papers in Economics and Informatics 11: 49-59. CrossRef.

Macedo A, Gouveia S, Rebelo J (2020) Horizontal differentiation and determinants of wine exports: Evidence from Portugal. Journal of Wine Economics 15: 163-180. CrossRef.

Morrison A, Rabellotti R (2017) Gradual catch up and enduring leadership in the global wine industry. Research Policy 46: 417-430. CrossRef.

Santeramo FG, Lamonaca E, Nardone G, Seccia A (2019) The benefits of country-specific non-tariff measures in world wine trade. Wine Economics and Policy 8: 28-37. CrossRef.

Silva JS, Tenreyro S (2006) The log of gravity. The Review of Economics and Statistics 88: 641-658. CrossRef.

Wei SJ (1996) Intra-national versus international trade: How stubborn are nations in global integration? National Bureau of Economic Research Working Paper 5531, Cambridge. https://ssrn.com/abstract $=4196$

\section{Acknowledgement}

The authors disclosed receipt of the following financial support for the research, authorship, and/or publication of this article: This work is supported by the project VINCI - Wine, Innovation and International Competitiveness, under the operation number SOE3/P2/F0917, FEDER - Interreg SUDOE, and national funds, through the FCT - Portuguese Foundation for Science and Technology under the project UIDB/SOC/04011/2020.

c) (7) (5) (C) 2020 by the authors. Licensee: REGION - The Journal of ERSA, European Regional Science Association, Louvain-la-Neuve, Belgium. This article is distributed under the terms and conditions of the Creative Commons Attribution, Non-Commercial (CC BY NC) license (http://creativecommons.org/licenses/by-nc/4.0/). 